International Journal of Life Sciences
Available online at www.sciencescholar.us
Vol. 5 No. 1, April 2021, pages: $14-25$
e-ISSN: 2550-6986, p-ISSN: $2550-6994$
https://doi.org/10.29332/ijls.v5n1.1137

\title{
Environmental Impact of Photovoltaic Solar Technology
}

\begin{abstract}
CrossMark
Telly Yarita Macías Zambrano a, Yoan Pablo Rodríguez Monier b, Jean Telmo Mendoza Mera ${ }^{c}$, Carmen Magdalena Mero Alcivar d, Anita dolores zambrano Valencia e, Douglas José Giler Loor ${ }^{\mathrm{f}}$

Manuscript submitted: 9 February 2021, Manuscript revised: 27 March 2021, Accepted for publication: 18 April 2021

Corresponding Author a

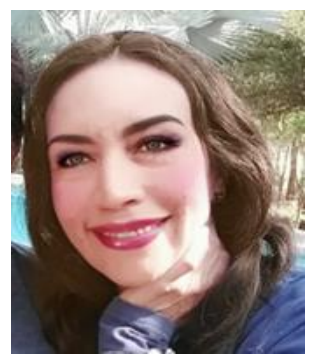

Keywords

ambiente; desarrollo local; desarrollo sostenible;

\section{Abstract}

The work presents an analysis linked to one of the environmentally sustainable energy alternatives that are currently being adopted with success Worldwide. Putting the field research method into practice, the results of a study related to an application of technological innovation are shown to reduce the amount of the electricity bill of a local teacher, through the introduction of photovoltaic technology connected to the low grid. Institution tension. The results of the load study and hourly energy consumption of said entity are shown and its own methodology is deployed for the technological design of a photovoltaic plant connected to the grid, which can avoid the energy consumption of the conventional grid, reducing the amount of the institution's electricity bill, at the same time that it is possible to reduce losses, improve the quality of electricity service and reduce COemissions2 into the atmosphere. The environmental and social impacts associated with the penetration of photovoltaic technology are exposed.
\end{abstract} energía solar; sostenibilidad;

\section{Contents}

Abstract

a Instituto Superior Tecnológico Paulo Emilio Macías, Portoviejo, Manabí

b Unidad Educativa, Capitán Giovanni Calles, Orellana, Ecuador

c Unidad educativa Pablo Zamora Salgado. Flavio Alfaro, Manabí, Ecuador

d Unidad educativa Jama, Manabí, Ecuador

e Unidad educativa Eloy Alfaro Bahía de Caráquez, Sucre, Manabí, Ecuador

${ }^{f}$ Unidad Educativa Areliza Leonor Vera Góngora, Tosagua, Manabí, Ecuador 


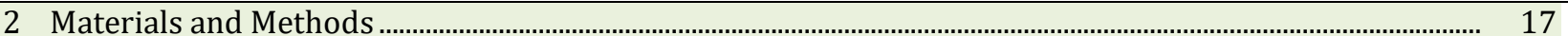

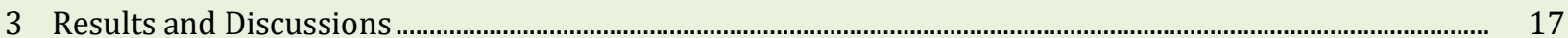

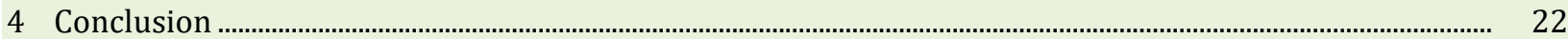

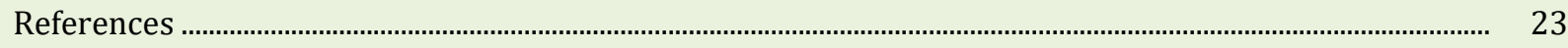

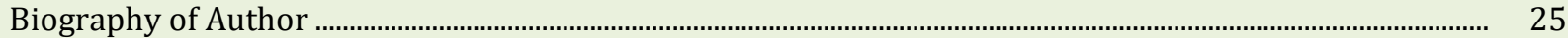

\section{Introduction}

The energy development of society has been an important step in the leap experienced by human progress. It is evident that without energy the accelerated development of the productive forces and the creation of the material base that allows man to abandon the first forms of life and to undertake new routes in the progress of humanity would not have been possible.

It is estimated that during the 6th century BC with the beginning of the Neolithic era, man began to control and rationally use energy in agriculture, as well as the use of animals for work and food preparation. Already in the 4th and 3rd centuries BC, the first great energy systems in history began, with the construction in the rain zones of the Tigris, the Euphrates and the Nile, of crop irrigation systems. Around this same time, an elementary machine was built for lifting weights based on the principle of the lever (Rodriguez, Vázquez, Castro, \& Vilaragut, 2012; O'Faircheallaigh, 2010; Cashmore, 2004; Tsoutsos et al., 2005).

Between the twelfth and seventeenth centuries there was a strong demand for energy for the processing and preparation of metals, considerably increasing the demand for wood to use as fuel. All of this led to a disproportionate advance in deforestation in many European regions. It is precisely in the seventeenth century, when as a result of poor management in the use of wood as fuel, an acute shortage of this resource is experienced in Western Europe, especially in the British Isles, where for the realization of industrial activities derived from thermal energy, it was necessary to start burning coal (Saltos, Rodríguez, Vázquez, \& Castro, 2016; Hischier et al., 2005; Veldkamp \& Verburg, 2004).

From the seventeenth century, the first industrial revolution began to develop, with the emergence of technologies such as the steam engine, the railway and textile machines, producing the first energy transition, where wood and charcoal were replaced by mineral coal. . Some centuries later, between 1860 and 1930, the second energy transition takes place, linked to the second industrial revolution, where electrical systems, aviation and the steel industry were introduced. In this stage, the mineral coal gives way to the preferential use of oil. As early as 1859, the first well for the extraction of oil in Pennsylvania had been dug by Seneca Oíl Co (Valls, 2019). In a short period of time during the second half of the 19th century, the share of oil in the world primary energy market, and by 1970 it was the basis of the first global energy supply system (Rodríguez, Vázquez, Sarmiento, \& Millet, 2017; Jay et al., 2007; Duinker \& Greig, 2007).

During the second half of the 20th century, the participation of fossil fuels in energy generation continued to increase and when the scenario of the new energy policies is described, it is suggested that global energy demand registers a strong rise and may increase by one third. from 2010 to 2035 (Vázquez, Rodríguez, Villacreces, \& Velez, 2017). The increase in excessive dependence on fossil fuels to obtain energy, were causing the depletion of their reserves, to such an extent that it is estimated according to a study published by the Organization of Petroleum Producing Countries (OPEC), that the supply of oil for the year 2037 and, on the other hand, with a high degree of complexity due to the danger posed by the burning of coal, oil and natural gas for the environment and the human species (Dávila, Dávila, Vázquez, \& Dávila, 2017).

International discussions about the causes and implications for humanity of the so-called "greenhouse effect", caused by the increasing emissions into the atmosphere of gases such as CO2, reflect the need for a comprehensive approach in the treatment of environmental problems and climate change. development, as well as the need for action by the international community to mitigate the effects of global warming. Electric energy is undoubtedly the most used resource in the world, it constitutes a technical element that is given vital importance for social development, however the intensive use of fossil fuels (oil, gas and coal), promote depletion of its reserves, at the same time that polluting effects can accumulate that put the stability of life on Earth at stake (Saltos, Intriago, Salvatierra, Vázquez, \& Rodríguez, 2017).

The combustion of fossil fuels is responsible for producing $80 \%$ of carbon dioxide (CO2) into the atmosphere, generating global warming. Some organizations have published information that reveals the

Zambrano, T. Y. M., Monier, Y. P. R., Mera, J. T. M., Alcivar, C. M. M., valencia, A. dolores zambrano, \& Loor, D.

J. G. (2021). Environmental impact of photovoltaic solar technology. International Journal of Life Sciences, 5(1), 14-25. https://doi.org/10.29332/ijls.v5n1.1137 
danger posed by the burning of coal, oil and natural gas, since the historical level of $\mathrm{CO} 2$ in the atmosphere had been between 180 to $280 \mathrm{ppm}$ and in little more than a hundred years it was It has risen to $400 \mathrm{ppm}$, a situation that if not controlled can generate a true global climate calamity (Medveczky \& Ochoa, 2012).

As a possible response to these natural impacts and the conservation of man's own life, a social commitment arises sufficiently understood by most human beings, which is committed to a scheme of progress that at the same time is respectful of nature and nature. human integrity, that is, it is projected for sustainable development, which promotes, among other elements, renewable sources of energy, which some times ago were not thought to have such an important participation in terms of electricity generation (Cabeza, 2018). International discussions about the causes and implications for humanity of the so-called "greenhouse effect", caused by the increasing emissions into the atmosphere of gases such as CO2, reflect the need for a comprehensive approach in the treatment of environmental problems and development, as well as the need for concerted action by the international community to mitigate the effects of global warming (Dávila et al., 2017).

For some years it has been strongly argued that renewable sources of energy that replace fossil fuels should be cleaner and should not produce more impacts that accelerate climate change. It is emphasized that as an additional advantage they should be located easily, with the least impact on the landscape and environmental conditions (Van, 2002). The answer lies in the environment: sunlight, wind, water, plants, the heat of the Earth. Some of these sources are very old. Since humans learned to make fire, they used wood to heat and cook. Windmills helped irrigate the fields of the ancient Persians. The ancient Greeks and Romans used the falling water to turn water wheels. However, at the beginning of the 20th century, in many places, supposedly cheaper fossil fuels, replaced almost all those traditional sources of energy supply (Rodríguez, Vázquez, Castro, \& Vilaragut, 2013).

On Earth, solar radiation is the main source of primary energy, which is transformed into electrical energy by photovoltaic conversion. It is practically inexhaustible, non-polluting, it is territorially distributed and its potential availability is much higher than the energy needs of man (Giraudy, Rodríguez, Massipe, Vázquez, \& Rodríguez, 2014). Unlike fossil fuels, solar energy does not produce carbon dioxide and therefore does not contribute to global warming. The most important thing is that unlike increasingly scarce fossil fuels, this source of energy will never end as long as man exists on the planet (Sarmiento, Castillo, Rodríguez, \& Vázquez, 2014).

Globally there is a growing awareness of the importance of renewable energy and energy efficiency, which constitute an alternative not only to address climate change, but to create new economic opportunities and provide access to energy to billions of people (REN 21,2015). During the past decade and particularly in recent years, there have been possible advances in renewable energy source technologies, increases in generation capacity worldwide, as well as rapid cost reductions thanks to the support provided by economic policies, which have attracted a significant amount of investment and drove costs down through economies of scale (REN 21, 2015).

Renewable energy continued to develop in 2014, even with growing global energy consumption and the dramatic decline in oil prices during the second half of 2015 as a backdrop. Also in 2014, renewable energy expanded significantly in terms of installed capacity and energy produced; while investments in renewable energy in the energy sector exceeded net investments for fossil fuel power plants. The fastest growth and the most substantial increase in renewable capacity worldwide were seen in the electricity sector, the dominant technologies were: wind, solar photovoltaic (PV) and hydropower (REN 21, 2015).

Policy support for renewables has contributed to market volume growth and high global competition. Significant cost reductions, especially for solar PV and wind, have played a role in the increasing electrification of transportation and heating appliances. This fact has also highlighted the potential for greater overlap between sectors in the near future. In many countries, renewable energies are highly competitive with conventional fuels, particularly in the electricity sector (REN 21, 2015). In developing countries, distributed power generation systems offer an unprecedented opportunity to accelerate the transition to modern energy services and increase access (Cabeza, 2018).

For its part, the Ecuadorian government closely follows the use of renewable energy sources with hydro, wind and solar generation projects in various sectors of the country. But the national bet is still focused on taking advantage of its water potential with large projects and investments. In Loja, the Villonaco Wind Farm is the largest project of its kind in the country, with 11 installed wind turbines that provide energy to the 
medium voltage distribution network. These equipments will generate $16.5 \mathrm{MWh}$ and their contribution to the country will be $0.03 \%$ to the National Interconnected System, being able to avoid the emission of 38,000t $\mathrm{CO} 2$ as well as the importation of a significant volume of diesel. These projects are promoted through Renewable Energy (Hernández, Vázquez, Rodríguez, Martínez, \& Torres, 2017).

Ecuador has caught up with the latest in photovoltaic and thermal technology. As an example, the Government implemented photovoltaic solar panels in eight communes in the Gulf of Guayaquil. The Eurosolar project aims to provide electricity to 91 isolated and poor communities with the help of the European Union. Although other projects have been developed through the introduction of facilities greater than 500kWp, (Vázquez, Loor, Cuenca, \& Hernández, 2016). However, the contribution of photovoltaic systems connected to the low voltage grid in the distributed generation mode is still poor and its essence and objectives are not adequately understood.

To obtain the expected results in a photovoltaic project, certain factors must be considered, which must be studied and analyzed in detail. The main thing to assess is the energy efficiency of the photovoltaic system to be installed, to achieve this, different elements that are related must be evaluated, such as the dimensions of the technology installation area, the average potential of daily solar energy, the angle of inclination of the modules, the level of shading present in the area, the quality and characteristics of the technology offered, the evaluation of possible damages caused by natural disasters and other aspects that can be analyzed in a particular way (Rodriguez, Vázquez, Saltos, \& Castillo , 2016).

The work offers a sustainable alternative to the problem of energy supply, where the results of the design of a photovoltaic system connected to the network in the teaching building of the Technical University of Manabí are exposed, which offers the possibility of reducing dependence on oil in the generation of electricity, contributing to the reduction of COemissions2 into the atmosphere.

\section{Materials and Methods}

Corresponds to a descriptive research, as it seeks to obtain information about photovoltaic systems, especially those that are connected to the low voltage network in the distributed generation mode and its application in the context of the study area in order to reduce the amount of the electricity bill, at the same time achieving a reduction in oil consumption and reducing $\mathrm{CO} 2$ emissions into the atmosphere from electricity generation. An evaluation was carried out on the application of photovoltaic technology and its economic, technical and environmental impact was verified. The basic method used is the exploratory one, in order to determine a group of data and situations that were unknown, among which are: the hourly consumption of electricity in the building; the incident solar potential at the installation site and; the specific productivity that can be achieved. In general, the investigative techniques of reviewing documents, texts, theses, books, newspapers, magazines, technical standards, web pages and manuals were used to obtain the appropriate and clear information for the proper development of the topic addressed.

\section{Results and Discussions}

\section{Generation in the province of Manabí}

The base generation in the province of Manabí depends on the use of oil through an inefficient and very expensive centralized system. This supposes a negative environmental and economic influence on energy consumption, since for each MWh of energy generated with thermal plants, up to 0.9 tons of COcan be emitted2 into the atmosphere, at the same time that oil is a resource that presents high prices in the market, leading to inefficient and expensive electrical service.

The electricity company has considered achieving a relevant social impact by increasing the energy supply and despite the use of various technologies aimed at guaranteeing a quality service, this last objective is achieved at a high economic and environmental price, since they are increasingly more numerous technologies that are incorporated to achieve it.

Zambrano, T. Y. M., Monier, Y. P. R., Mera, J. T. M., Alcivar, C. M. M., valencia, A. dolores zambrano, \& Loor, D. J. G. (2021). Environmental impact of photovoltaic solar technology. International Journal of Life Sciences, 5(1), 
The so-called renewable sources of energy, thus known for their agile and natural ability to generate themselves, cover only $12.9 \%$ of the global energy demand worldwide. This last percentage is broken down as follows: biomass energy generated with organic elements derived from crops (10.2\%) hydraulic (2.3\%); wind energy (0.2\%); geothermal and solar (0.2) (Schallenberg \& et al, 2008). In the province of Manabí and especially in the city of Portoviejo, photovoltaic energy has the capacity to guarantee a quality electrical service, reducing the economic and environmental impact in the generation of electricity, elements that constitute a challenge for schools and colleges.

The various reforms carried out in Ecuador have been generating a whole procedure that favors energy saving, but nothing forceful and specific as something as clear and efficient as clean energy. For this, educational centers have in their academic and research development plans projects that involve public spaces, which complement the programs that help increase renewable energies, transforming the energy monopoly into a diverse renewable matrix of distributed generation and sustained use of renewable sources that are available in the territories (Cabeza, 2018). In the province of Manabí, photovoltaic energy has the ability to guarantee quality electricity service, reducing the economic and environmental impact of electricity generation.

\section{Alternative sustainable solution to the supply of electrical energy}

The research proposed an alternative of sustainable solution to the supply of electrical energy, achieving at the same time the saving of resources, the reduction of the electricity bill and the reduction of COemissions 2 into the atmosphere. In the constitution of the Republic of Ecuador in article 14 it is stated verbatim "The right of the population to live in a healthy and ecologically balanced environment is recognized, which guarantees sustainability and good living, sumak kawsay. The preservation of the environment, the conservation of ecosystems, biodiversity and the integrity of the country's genetic heritage, the prevention of environmental damage and the recovery of degraded natural spaces are declared of public interest (Constituent Assembly, 2008).

In the Constitution itself in article 413 it is stated verbatim: "The State shall promote energy efficiency, the development and use of environmentally clean and healthy practices and technologies, as well as diversified renewable energies, of low impact and that do not put the food sovereignty, the ecological balance of ecosystems and the right to water. Later in article 414 it is stated textually: "The State will adopt adequate and transversal measures for the mitigation of climate change, by limiting greenhouse gas emissions, deforestation and atmospheric pollution; (Constituent Assembly, 2008). In the Organic Code of Production, Trade and Investments of Ecuador, article 9.1 prioritizes the development of applications based on renewable energy sources (National Assembly, 2010).

In the National Plan for Good Living 2013-2017 (SENPLADES, 2013) in Chapter 5.1.4. Productive Matrix and Strategic Sectors is expressed verbatim: "Parallel to the execution of large hydroelectric projects, in 2030 the electricity supply will be complemented by the implementation of small energy generation projects with renewable sources such as: photovoltaic, wind, biomass and hydroelectricity in areas close to consumers, and with participatory management schemes of Decentralized Autonomous Governments, community organizations and the private sector. These projects make renewable energies available for local productive uses and the interconnected system, which allows generating local employment, optimizing the use of natural resources, diversifying territories in electricity generation and reducing technical losses in electricity transmission.

\section{The solar potential}

The Sun can satisfy the energy needs if it is possible to know the ways of how to use in a rational way the energy that it subsequently spreads on the planet. For this, capture and transformation systems are used that are developed with the progress of science and technology. Among the advantages of this energy are its high quality, distributed character and relatively low environmental impact. All world energy consumption can be covered with the use of solar energy in the different variants of its use (Alvarez, 2020). Considering the distance that separates the Sun from the Earth, the proportion of radiant energy that the planet receives with respect to the total emitted by the Sun is barely one thousandth part per million, but even so, $1.51 \times$ reaches 
the Earth. $\left(10^{\wedge} 18 \mathrm{kWh} /\right.$ year, this amount is equivalent to several thousand times the energy used by all of humanity (Sarmiento, 2013).

Variables that can affect solar radiation among the variables that can affect solar radiation the most is cloudiness the estimation of energy generation must consider the unstable nature of the primary source (the Sun), which presents fluctuations during the day due to the cloudiness that supposes a high variability, increasing or decreasing according to the seasons of the year, and specifically in some territories it may be higher or lower (Díaz, Vázquez, \& Rodriguez, 2012). Solar potential means the equivalent power of solar energy that reaches the horizontal plane of the earth in one day. a and is expressed in: $\mathrm{kWh} / \mathrm{m} 2$ day. The province of Manabí has one of the highest values of solar potential that affects Ecuador as an average. The average intensity of solar radiation in the province is equivalent to half a liter of oil per square meter daily.

\section{Visualization of the scope of the study}

The developed project is capable of displaying economic, social, environmental and scientific scope. The economic scope lies in the very nature of the proposal, since it is intended to introduce a technical alternative that generates a virtual cost equal to zero for fuel and lubricant consumption; capable of reducing losses; with the potential to increase the oil independence of electricity generation, which enables a significant reduction in the cost of the kWh generated and served to users, being able to save foreign exchange for oil avoided in power generation.

The proposed energy solutions generate potential to reduce the electricity bill. Currently, when the externalities generated by traditional electricity service are considered, the real unsubsidized cost of kWh served to end users can be between USD 0.35 and USD 0.42, depending on the losses. However, the cost of the photovoltaic kWh generated in the distributed generation mode and served to the end users may be costing between $\$ 0.10$ and $\$ 0.23$, depending on the price of the photovoltaic technology at the time of purchase. (Rodríguez \& Vázquez, 2015).

In the social sphere, it constitutes the proposal of a sustainable solution to the diversification of the energy matrix in the territory, since it contributes to the relocation of energy sources, which represents the introduction of a new philosophy of generating and consuming energy, where the consumer it can become the generator of its own energy, making society the protagonist of energy management. The applications are focused on guaranteeing a higher quality and reliability of the electricity service, helping to improve the institutional image of the energy sector before society.

From the environmental point of view, the scope is guaranteed to the extent that the introduction of photovoltaic technology manages to reduce the emissions of polluting gases into the atmosphere due to the generation of electricity. For every MWh of electricity generated in a thermal plant that consumes oil, 0.25 tonnes of $\mathrm{CO} 2$ are emitted2 into the atmosphere, which can be avoided with photovoltaic technology. Until now, most of the photovoltaic applications that have been carried out in Ecuador are due to centralized installations connected to the distribution network of the National Interconnected System. From this point of view, the scientific scope lies in the novelty of the content of the topic being addressed, since it is a specific application in the distributed generation mode, capable of reducing losses and ensuring that the consumer generates their own energy, which makes it a protagonist of energy management. The results of the research can be used by other students, professors and researchers who venture into the study of the subject matter.

\section{Definition of the initial study sample and access to it}

For the interview, the population is made up of teachers. Given the characteristics of the population, no equation is required to define said sample. Figure 1 shows the opinions provided by the specialists based on the possibility of improving the electricity service by applying photovoltaic technology.

Zambrano, T. Y. M., Monier, Y. P. R., Mera, J. T. M., Alcivar, C. M. M., valencia, A. dolores zambrano, \& Loor, D. J. G. (2021). Environmental impact of photovoltaic solar technology. International Journal of Life Sciences, 5(1), 


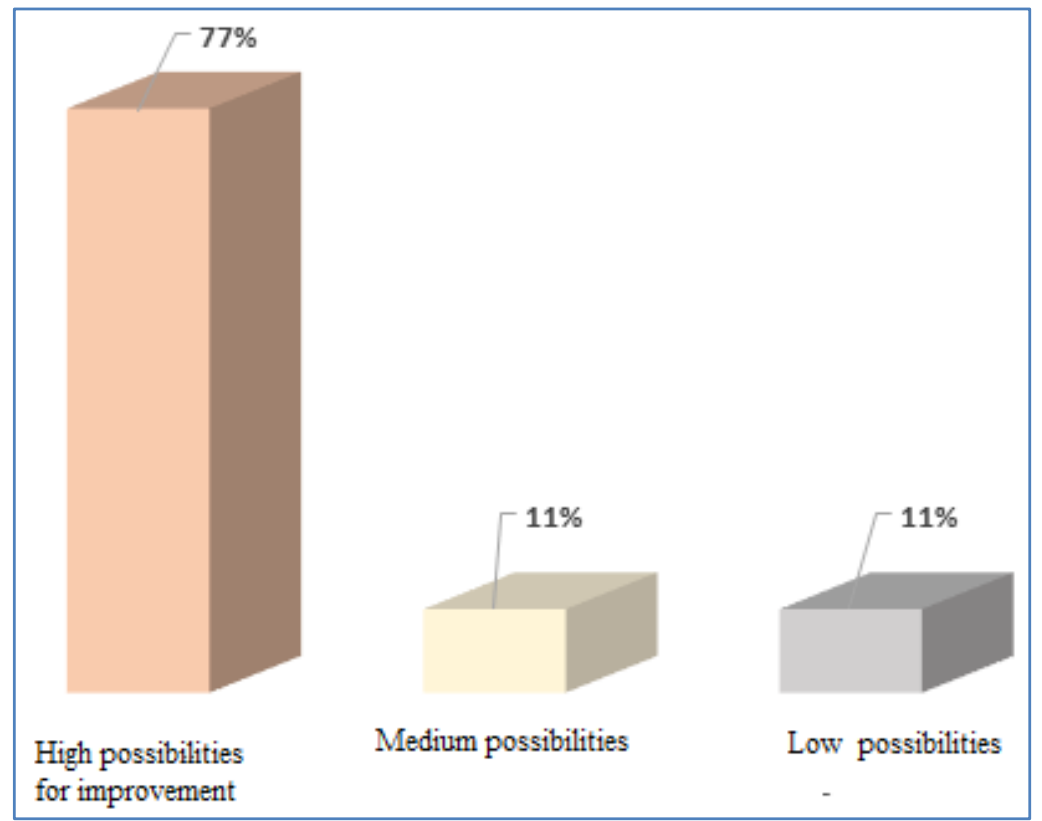

Figure 1. Opinions provided by specialists

Source: Encased teachers

It can be seen that most of the interviewed teachers believed that the possibility of improving electricity service through the application of solar energy technology is high. The specialists believed that electricity generation systems using solar energy are based on the ability of photovoltaic cells to transform light radiation from the Sun into electrical energy in the form of direct current (DC). This means that the consumption of any other fuel for generation is zero and therefore COemissions 2 are practically symbolic. In a system connected to the grid, the energy through the use of an inverter is transformed into alternating current, which can be used in homes or institutions with the ability to avoid fossil fuels to generate electricity and improve the grid voltage profile together with other benefits that are only achieved with the use of solar energy in the distributed generation mode (Soto I. E, 2005). Considering the aforementioned, it can be defined that the introduction of solar energy in the technical format of connecting the low voltage network, taking advantage of the distributed generation mode, can achieve oil savings, reducing the electricity bill of the institution and at the same time contribute to the reduction of COemissions 2 into the atmosphere. Table 1 shows the results of the analysis regarding the impact of solar energy on the preservation of natural resources.

Table 1

Impact of solar energy on the preservation of natural resources

\begin{tabular}{llll}
\hline No & Criteria & Frequency & $\%$ \\
\hline A & $\begin{array}{l}\text { High impact on the preservation of natural } \\
\text { resources }\end{array}$ & 9 & 100 \\
B & $\begin{array}{l}\text { A medium impact on the preservation of } \\
\text { natural resources }\end{array}$ & 0 & 0 \\
C & $\begin{array}{l}\text { A low impact on the preservation of natural } \\
\text { resources }\end{array}$ & 0 & 0 \\
\hline \multicolumn{1}{c}{ Preparation: teachers surveyed }
\end{tabular}

It was found that All of the specialists surveyed believed that solar energy can have a high impact on the preservation of natural resources, since in the province of Manabí the generation of electricity has a thermal origin through the use of oil and it is known that the index of fuel consumption for electricity generation is 
approximately 0.25 tons of oil for each MWh of electricity generated ( 0.25 tons / MWh). This means that for every $4 \mathrm{MWh}$ of photovoltaic energy that can be generated, a ton of oil is being saved. It was consulted in which measures it is considered that the use of solar energy can contribute to the protection of the environment, obtaining the following results in figure 2 the results are shown.

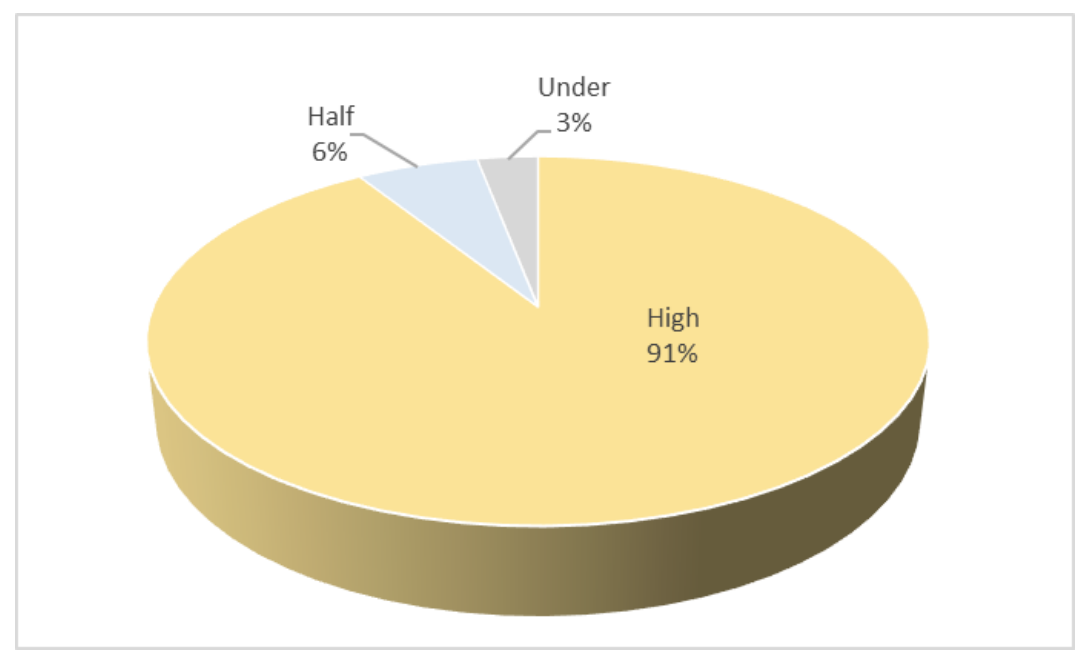

Figure 2. Solar energy can contribute to environmental protection

$91 \%$ of those surveyed stated that the use of solar energy can create high benefits for environmental protection; $6 \%$ consider that the benefits may be medium; while 3\% believed that these benefits are low. According data published by the International Energy Agency, chen the environmental impact of electricity generation are analyzed by burning oil, you can verify that for each MWh generated are emitted 0.9 tonnes ofCO2 into the atmosphere, resulting a highly polluting and damaging technical operation of environmental conditions, mainly increases the greenhouse effect. It can be affirmed that the polluting factor derived from the generation of electricity with the use of oil can experience a high reduction when the use of solar energy is implemented (Intriago \& Salvatierra, 2015).

\section{Environmental impact}

The study of environmental impacts is carried out with the objective of determining the impact on the environment that can be caused by the introduction of photovoltaic technology and these must be studied in two directions: the negative effects on the environment of the site where the technology is installed; and the environmental benefits that are achieved by reducing fossil fuel consumption as a consequence of the introduction of photovoltaic technology.

The main negative environmental effects associated with the introduction of photovoltaic technology will be related to the occupation of space and the visual intrusion to the landscape caused by the introduction of the equipment. The location of the photovoltaic modules creates a compromise of space occupation. Among the environmental benefits and advantages of photovoltaic technology we can point out the following: it does not emit noise when operating; it has no moving parts; it does not need to be stocked; It does not emit polluting gases in its exploitation stage and; When installed on the roof of the building, it can reduce the transfer of heat to the interior, benefiting the air conditioning of the premises and thus saving energy by the climate equipment. These characteristics make it a valuable technological solution to reduce environmental impacts.

When the losses associated with the centralized power generation and supply system are considered, it can be stated that for each kWh of photovoltaic energy supplied in the distributed mode of direct connection to the building's low-voltage grid, more than $1 \mathrm{kWh}$ of electricity generated with fossils, so it can have an added value of reducing environmental impacts. If the oil avoided by photovoltaic generation and the reduction of losses is considered, it can be estimated that for each MWh of photovoltaic electricity generated,

Zambrano, T. Y. M., Monier, Y. P. R., Mera, J. T. M., Alcivar, C. M. M., valencia, A. dolores zambrano, \& Loor, D. J. G. (2021). Environmental impact of photovoltaic solar technology. International Journal of Life Sciences, 5(1), 
the emission of 0.9 tons of $\mathrm{CO} 2$ can be avoided. Considering the energy productivity of the proposed photovoltaic power plant, it can be estimated that in one year of generation it will be possible to reduce more than 40 tons of $\mathrm{CO} 2$ emissions into the atmosphere.

\section{Social impact}

Social impact is an element that can hardly be achieved through traditional ways of implementing energy. Photovoltaic technology allows, like no other source, the relocation of the energy resource very close to the social actors that consume electricity and this can be an influential element for the adoption of new positions of consumption and responsibility based on the preservation of resources and the adoption of energy use and expenditure patterns appropriate to the real needs of work and people.

\section{Conclusion}

Photovoltaic generation can avoid the annual emission of about 40 tons of CO2, by concept of oil avoided in the generation of electricity, in addition it can generate other benefits associated with the protection of natural resources by avoiding the annual consumption of more than 1 ton of oil. 


\section{References}

Álvarez, P. E, (2020). Energía y Cambio Climático. Real Academia de Ingenieria. https://issuu.com/raing/docs/energ_a_y_cambio_clim_tico._format

Asamblea Constituyente. (2008). Constitution of the Republic of Ecuador. Decreto Legislativo 0, Registro Oficial 449 de 20-oct-2008, Ultima modificación: 13-jul-2011. Estado: Vigente, Disponible en: http://www.oas.org/juridico/pdfs/mesicic4_ecu_const.pdf.

Asamblea Nacional. (2010). Código Orgánico de la Producción, Comercio e Inversiones. Registro oficial del Órgano de Gobierno del Ecuador., Disponible en: http://www.wipo.int/edocs/lexdocs/laws/es/ec/ec050es.pdf.

Cabeza, CJV (2018). Estudio del potencial disponible en el edificio 3 para aumentar la generación por energía solar. Facultad de Ciencias Matemáticas, Físicas y Químicas. trabajo de titulación previo para obtener el título de Ingeniero Electricicsta, Repositorio de la biblioteca de la Universidad Técnica de Manabí.

Cashmore, M. (2004). The role of science in environmental impact assessment: process and procedure versus purpose in the development of theory. Environmental Impact Assessment Review,24(4), 403-426. https://doi.org/10.1016/j.eiar.2003.12.002

Dávila, CML, Dávila, AMG, Vázquez, PA, \& Dávila, AML (2017). Regulatory Framework for Renewable Energy Sources in Ecuador Case Study Province of Manabí. International Journal of Social Sciences and Humanities (IJSSH), [Sl]. ISSN 2550-7001. Available at: http://sciencescholar.us/journal/index.php/ijssh/article/view/33. Date accessed: 16 nov. 2017. doi: http://dx.doi.org/10.21744/ijssh.v1i2.33., v. 1, n. 2. aug. 2017, 29-42.

Díaz, SR, Vázquez, PA, \& Rodriguez, GM (2012). Normas técnicas y sistemas fotovoltaicos conectados a red. Revista CUBASOLAR. www.cubasolar.cu/biblioteca/Ecosolar/Ecosolar39/HTML/Articulo02N.htm, Centro de Investigaciones y Pruebas Electroenergéticas (CIPEL), Instituto Superior Politécnico José Antonio Echeverría (CUJAE). La Habana. Cuba

Duinker, P. N., \& Greig, L. A. (2007). Scenario analysis in environmental impact assessment: Improving explorations of the future. Environmental impact assessment review,27(3), 206-219. https://doi.org/10.1016/j.eiar.2006.11.001

Giraudy, ACM, Rodríguez, GM, Massipe, CI, Vázquez, PA, \& Rodríguez, RR (2014). Factibilidad de instalación de sistemas fotovoltaicos conectados a red. Ingeniería Energética, Vol. XXXV, No. 2/ 2014 Mayo/ Agosto , ISSN $1815-5901$.

Hernández, CJC, Vázquez, PA, Rodríguez, GM, Martínez, GAA, \& Torres, BOE (2017). Use of Small Wind Turbines in Isolated Areas Social Impact. International Research Journal of Engineering, IT \& Scientific Research (IRJEIS). Available online at http://ijcu.us/online/journal/index.php/irjeis, Vol. 3 Issue 2, March 2017, ISSN: 2454-2261 Impact Factor: 5.211 | Thomson Reuters: K-4290-2016: http://dx.doi.org/10.21744/irjeis.v3i2.415, 84 90.

Hischier, R., Wäger, P., \& Gauglhofer, J. (2005). Does WEEE recycling make sense from an environmental perspective?: The environmental impacts of the Swiss take-back and recycling systems for waste electrical and electronic equipment (WEEE). Environmental Impact Assessment Review, 25(5), 525-539. https://doi.org/10.1016/j.eiar.2005.04.003

Intriago, C. Gabriela, \& Salvatierra Ch Susana. (2015). "Implementación de tecnología fotovoltaica conectada a la red para suministrar energía eléctrica al segundo y tercer piso del edificio no 3 de docentes a tiempo completo de la Universidad Técnica de Manabí, el ahorro y la eficiencia energética". Facultad de Ciencias Matemáticos, Físicas y Químicas de la Universidad Técnica de Manabí, Disponible en el repositorio de la biblioteca de la Universidad Técnica de Manabí.

Jay, S., Jones, C., Slinn, P., \& Wood, C. (2007). Environmental impact assessment: Retrospect and prospect. Environmental impact assessment review, 27(4), 287-300. https://doi.org/10.1016/j.eiar.2006.12.001

Medveczky, OD, \& Ochoa, CJ (2012). Tesis previa a la obtención de título de ingeniero eléctrico. Universidad de Cuenca.

O'Faircheallaigh, C. (2010). Public participation and environmental impact assessment: Purposes, implications, and lessons for public policy making. Environmental impact assessment review, 30(1), 19-27. https://doi.org/10.1016/j.eiar.2009.05.001

Zambrano, T. Y. M., Monier, Y. P. R., Mera, J. T. M., Alcivar, C. M. M., valencia, A. dolores zambrano, \& Loor, D. J. G. (2021). Environmental impact of photovoltaic solar technology. International Journal of Life Sciences, 5(1), 
REN 21. (2015). Reporte de la situación mundial de las energías renovables 2015. Hallazgos claves 2015. Renewable energy polici network. ISBN 978-3-9815934-7-1.

Rodríguez, GM, Vázquez, PA, Castro, FM, \& Vilaragut, LM (2012). Sistemas fotovoltaicos y la ordenación territorial. Revista Energética. Ingeniería Energética. versión On-line ISSN 1815-5901, vol.34 no.3 La Habana sep.-dic. 2013.

Rodríguez, GM, Vázquez, PA, Castro, FM, \& Vilaragut, LM (2013). Sistemas fotovoltaicos y la ordenación territorial. Revista: Ingeniería Energética. versión On-line ISSN 1815-5901, Energética vol. 34 no.3 La Habana sep.-dic. 2013.

Rodriguez, GM, Vázquez, PA, Saltos, AWM, \& Castillo, JWC (2016). Sustainable Transformation of Energy Matrix. International Research Journal of Engineering, IT \& Scientific Research (IRJEIS) Available online at http://ijcu.us/online/journal/index.php/irjeis, Vol. 2, Issue 9, September 2016; ISSN: 2454-2261 Impact Factor: 3.605 | Thomson Reuters: K-4290-2016 : http://dx.doi.org/10.21744/irjeis.v2i9.231 http://orcid.org/0000-0001-9998-6145, 28 33.

Rodríguez, GM, Vázquez, PA, Sarmiento, SA, \& Millet, RZ (2017). Renewable Energy Sources and Local Development. International Journal of Social Sciences and Humanities. Available online at http://sciencescholar.us/journal/index.php/ijssh. e-ISSN: 2550-7001, p-ISSN: 2550-701X, Vol. 1 No. 2, August 2017, pages: (10 19).

Saltos, AWM, Intriago, CG, Salvatierra, CS, Vázquez, PA, \& Rodríguez, GM (2017). Microgrid With a 3.4 kWp Photovoltaic System in the Universidad Técnica de Manabí. International Journal of Physical Sciences and Engineering. Available online at http://sciencescholar.us/journal/index.php/ijpse. ISSN : 2550-6943, pISSN : 2550-6951. http://dx.doi.org/10.21744/ijpse.v1i2.34, Vol. 1 No. 2, August 2017, 11 20.

Saltos, AWM, Rodríguez, GM, Vázquez, PA, \& Castro, FM (2016). Microgrids Views from a Geographic Information System. International Research Journal of Engineering, IT \& Scientific Research (IRJEIS). Available online at http://ijcu.us/online/journal/index.php/irjeis. ISSN: 2454-2261 Impact Factor: 3.605 | Thomson Reuters: K-4290-2016. http://dx.doi.org/10.21744/irjeis.v2i11.308. http://orcid.org/00000002-4123-2823, Vol. 2, Issue 11, November 2016, 51 57.

Sarmiento, SA (2013). Energía Solar Fotovoltaica. Temas seleccionados. Editorial Academia., Editor 2013: Empresa de Gestión del Conocimiento y la Tecnología, Gecyt. Cuba.

Sarmiento, SA, Castillo, CO, Rodríguez, GM, \& Vázquez, PA (2014). Sistemas Integrados de energías con fuentes renovables, requisitos y opciones. Ingeniería Energética, Vol. XXXV, No. 1/ 2014 Enero/Abril ISSN 1815 5901, 71-78.

Schallenberg, Julieta \& et al, 2008). Energías renovables y eficiencia energética. ISBN 978-84-69093-86-3, https://www.cienciacanaria.es/files/Libro-de-energias-renovables-y-eficiencia-energetica.pdf.

SENPLADES. (2013). Plan Nacional del Buen Vivir 2013-2017. Secretaría Nacional de Planificación y Desarrollo - Senplades, 2013 Quito, Ecuador (primera edición). ISBN-978-9942-07-448-5. Disponible en: http://documentos.senplades.gob.ec/Plan\%20Nacional\%20Buen\%20Vivir\%202013-2017.pdf.

Soto I E. (2005). Celdas fotovoltaicas en la generación distribuida. Santiago de Chile. Tesis Consultado diciembre 2015. http://web.ing.puc.cl/power/paperspdf/pereda.pdf, 7.

Tsoutsos, T., Frantzeskaki, N., \& Gekas, V. (2005). Environmental impacts from the solar energy technologies. Energy policy, 33(3), 289-296. https://doi.org/10.1016/S0301-4215(03)00241-6

VALLS, XAVIER (2019). Pensilvania: el lugar donde nació el "oro negro". https://www.lavanguardia.com/historiayvida/historia-contemporanea/20191009/47853320440/oronegro-petroleo-pioneros-estados-unidos.html

Van, DW (2002). La cooperación transnacional, un instrumento al servicio del desarrollo rural. Cooperación internacional entre territorios rurales. Consultado diciembre 2017. Disponible en: http://ec.europa.eu/agriculture/rur/leader2/rural-es/coop/coop1.pdf.

Vázquez, PA, Loor, CGA, Cuenca, ALA, \& Hernández, CJC (2016). The Regulatory Framework for Renewable Energy Sources. International Research Journal of Management, IT \& Social Sciences (IRJMIS) Available online at http://ijcu.us/online/journal/index.php/irjmis, Vol. 3 Issue 11, November 2016, ISSN: 23957492 Impact Factor: 3.552 | Thomson Reuters: K-4291-2016: http://dx.doi.org/10.21744/irjmis.v3i11.302 http://orcid.org/0000-0001-9998-6145, 7 19.

Vázquez, PA, Rodríguez, GM, Villacreces, VCG, \& Velez, QAM (2017). Community Power as a Driving Force for Sustainable Local Development. International Research Journal of Engineering, IT \& Scientific Research 
(IRJEIS). Available online at http://ijcu.us/online/journal/index.php/irjeis. ISSN: 2454-2261 Impact Factor: 5.211 | Thomson Reuters: K-4290-2016, Vol. 3 Issue 4, July 2017, 7 17.

Veldkamp, A., \& Verburg, P. H. (2004). Modelling land use change and environmental impact. https://doi.org/10.1016/j.jenvman.2004.04.004

\section{Biography of Author}

\begin{tabular}{|l|l||}
\hline & $\begin{array}{l}\text { Telly Yarita Macías Zambrano } \\
\text { Industrial Engineer, Projects Specialization, Master in Agricultural Engineering. } \\
\text { Professor-Researcher at the Instituto Superior Tecnológico Paulo Emilio Macías. } \\
\text { External evaluator of research papers. Investment and social projects advisor } \\
\text { FUNDACMA. } \\
\text { Email:yoanpablo2283@gmail.com }\end{array}$ \\
\hline
\end{tabular}

Zambrano, T. Y. M., Monier, Y. P. R., Mera, J. T. M., Alcivar, C. M. M., valencia, A. dolores zambrano, \& Loor, D. J. G. (2021). Environmental impact of photovoltaic solar technology. International Journal of Life Sciences, 5(1), 14-25. https://doi.org/10.29332/ijls.v5n1.1137 